\title{
Effects of incubation temperature and bicarbonate on maturation of pig oocytes in vitro
}

\author{
L. A. Eng, E. T. Kornegay*, J. Huntington and T. Wellman \\ Division of Veterinary Biology and Clinical Studies, Virginia-Maryland Regional College of \\ Veterinary Medicine, and ${ }^{*}$ Department of Animal Science, Virginia Polytechnic Institute and State \\ Universities, Blacksburg, Virginia 24061, U.S.A.
}

\begin{abstract}
Summary. Pig oocytes cultured at $39^{\circ} \mathrm{C}$ had a higher percentage of polar body formation than did those cultured at $37^{\circ} \mathrm{C}$. A culture medium based on Medium 199 with Earle's salts and supplemented with $15 \%$ serum from a young castrated boar was just as good as the same formulation containing additional pyruvate, lactate and insulin, and superior to a modified Krebs-Ringer bicarbonate medium.

When the bicarbonate buffer system (Earle's salts) of Medium 199 was replaced with a phosphate buffer system (Hank's salts), the rate of polar body formation was decreased. When the Hank's based medium was supplemented with a bicarbonate buffer system, polar body formation was restored to the level in Earle's based medium. This suggests that $\mathrm{CO}_{2}$ /bicarbonate may be important for the normal maturation of pig oocytes.
\end{abstract}

\section{Introduction}

The successful development of mammalian fertilized ova and preimplantation embryos in vitro requires the presence of bicarbonate in the culture medium (Quinn \& Wales, 1973; Kane, 1975). The role of bicarbonate may be more than acting simply as a buffer system. Quinn \& Wales (1971, 1974) found that ${ }^{14} \mathrm{CO}_{2}$ was incorporated mainly into amino acids and protein, probably by the pyruvate carboxylase mediated condensation of carbon dioxide with pyruvate to form oxaloacetate. Radiolabel was found also in acetate, malate, ketoglutarate, and citrate (Wales, Quinn \& Murdoch, 1969) in mouse and rabbit embryos, and in lactate and pyruvate in rabbit embryos. Kane (1975) reported that 1-cell rabbit zygotes develop to morula in medium buffered by $N$-2-hydroxyethyl piperazine- $N^{\prime}-2$ ethanesulphonic acid (Hepes), but that bicarbonate was necessary for development to the blastocyst stage.

The maturation in vitro of oocytes aspirated from preovulatory follicles has been described for many mammalian species. Most investigations utilized a bicarbonate buffering system that was maintained by incubation in an atmosphere of $5 \% \mathrm{CO}_{2}$ in air, although some (Peluso \& Hutz, 1980; Dekel, Aberdam \& Sherizly, 1984; Racowsky \& Satterlie, 1985) have not done so. Nearly all previous studies have maintained cultures at $37^{\circ} \mathrm{C}$. The normal body temperature of pigs is $39^{\circ} \mathrm{C}$. The present study was undertaken to determine the effects of temperature and of bicarbonate versus phosphate buffering systems on the maturation of pig oocytes in vitro.

\section{Materials and Methods}

Culture media. Pig serum was collected from castrated boars at 10-11 weeks of age, and stored at $-76^{\circ} \mathrm{C}$ in $500 \mathrm{ml}$ samples. Before use, the serum was heat-treated at $56^{\circ} \mathrm{C}$ for $1 \mathrm{~h}$, centrifuged at $47800 \mathrm{~g}$ for $20 \mathrm{~min}$ at $4^{\circ} \mathrm{C}$, and passed through $5.0 \mu \mathrm{m}, 0.45 \mu \mathrm{m}$, and $0.22 \mu \mathrm{m}$ membrane filters 
under pressure. The serum was then added to sterile medium for immediate use, or stored at $-20^{\circ} \mathrm{C}$ for later use. Serum steroid hormones were assayed by radioimmunoassay (RIA; Jaffe \& Behrman, 1974). Concentrations of oestradiol, testosterone, and dihydrotestosterone were $<0.5 \mathrm{ng} / \mathrm{ml}$, while progesterone was measured at $0.51 \mathrm{ng} / \mathrm{ml}$.

Several culture media were utilized in these experiments. Most of the Medium 199 was purchased from GIBCO Laboratories, Grand Island, New York. Some was obtained from KC Biological, Inc., Lenexa, Kansas. TC-199H consisted of Medium 199 with Hank's salts, $1 \mathrm{~mm}$-glutamine, $10 \mathrm{~mm}$-Hepes, $15 \%$ pig serum, and $50 \mu \mathrm{g}$ gentamycin sulphate $/ \mathrm{ml}$. TC-199E was the same as TC-199H, but with Earle's salts. TC-199MH was the same as TC-199H, but with the same amount of sodium bicarbonate as TC-199E $(2 \cdot 2 \mathrm{~g} / 1)$. TC-199TC was the same as TC-199E, but further supplemented with $0.03 \mathrm{~mm}$-pyruvate, $2.5 \mathrm{~mm}$-lactate and $12.5 \mathrm{mU}$ insulin/ml (Iletin I, bovine and porcine mixture, $100 \mathrm{i} . \mathrm{u} . / \mathrm{ml}$ Eli Lilly \& Co., Indianapolis, IN), and was essentially identical to a formulation described by Tsafriri \& Channing (1975) to be optimal for maturation of pig oocytes. A modified Krebs-Ringer bicarbonate medium was prepared according to Toyoda \& Chang (1974), substituting $50 \mu \mathrm{g}$ gentamycin/ml for the original antibiotics.

Pyruvate and lactate concentrations in culture media and components were determined with enzyme assay kits purchased from Sigma Chemical Company, St Louis, MO (Pyruvate Kit 726; Lactate Kit 826).

Collection of oocytes. Ovaries were obtained at a local abattoir. Pigs were rendered unconscious by a blow to the head with a captive bolt and killed by exsanguination. The carcasses were skinned and the ovaries removed within $5 \mathrm{~min}$. The ovaries were pooled until approximately 50 had been collected $(2 \mathrm{~h})$. During this time; the ovaries were maintained at a temperature of $25-27^{\circ} \mathrm{C}$. Medium-sized follicles (3-7 mm diameter) were then gently aspirated with a $3 \mathrm{ml}$ syringe equipped with a 23-gauge short-bevel needle. The pooled follicular contents were centrifuged at $57 \mathrm{~g}$ for $15 \mathrm{sec}$ and the supernatant fluid was removed. The pelleted cumulus-oocyte complexes were resuspended $\left(60-80\right.$ oocytes $/ 12 \mathrm{ml}$ tube) in $\mathrm{TC}-199 \mathrm{H}$ and maintained at $39^{\circ} \mathrm{C}$ during the $30 \mathrm{~min}$ journey to the laboratory.

The collected oocytes were rinsed twice in $\mathrm{TC}-199 \mathrm{H}$ and then distributed to various media as described below for culture. Only oocytes with tightly adherent cumulus cells were cultured. Oocytes without cumulus cells were discarded.

Culture procedures. Cultures were routinely performed in $35 \times 10 \mathrm{~mm}$ Lux Contur dishes (Miles Scientific, Naperville, Illinois) with 30-50 cumulus-oocyte masses in a volume of $2 \mathrm{ml}$ culture medium. Except as noted below, the dishes were incubated at $39^{\circ} \mathrm{C}$ in an humidified atmosphere of $5 \% \mathrm{CO}_{2}$ in air. After $46-48 \mathrm{~h}$ incubation, the oocytes were removed for examination. At this time it was noted that many of the cumulus cells had separated from the cumulus-oocyte complexes and were firmly adherent to the dish.

Maturation scoring. The criterion for maturation was presence of a polar body. Most of the still-adhering cumulus cells were removed by repeated pipetting with a fine-bore pipette. Oocytes were then aspirated into a $0.3 \mathrm{~mm} \times 0.3 \mathrm{~mm}$ square capillary (Microcell 8330, Vitro Dynamics, Rockaway, NJ) and examined at $\times 200$ magnification with a Nikon Labophot equipped with Nomarski differential interference optics. The contents of each capillary were examined four times, rotating $90^{\circ}$ around the long axis after each examination until each oocyte had been viewed from 4 sides. The presence or absence of a polar body was noted for each oocyte.

Statistical analysis. Each experiment consisted of a comparison between two treatments. In each experiment, the oocytes were allocated equally between the treatments. The ratios of eggs with polar bodies/total eggs cultured were compared by a test for two proportions based on the large sample normal approximation to the distribution of the difference in sample proportion (Bailey, 1981). 


\section{Results}

The effects of culture media and incubation conditions on polar body formation are summarized in Table 1.

Table 1. The effects of various incubation conditions on polar body formation during maturation of pig oocytes in vitro

\begin{tabular}{|c|c|c|c|c|}
\hline \multirow{2}{*}{$\frac{\text { Exp. }}{1}$} & \multicolumn{2}{|c|}{$\begin{array}{c}\text { Treatments } \\
\text { PBF/eggs }(\% \text { PBF })\end{array}$} & \multirow{2}{*}{$\begin{array}{c}\begin{array}{c}\text { No. of } \\
\text { replicates }\end{array} \\
6\end{array}$} & \multirow{2}{*}{$\begin{array}{c}\text { Significance } \\
\quad P<0.001\end{array}$} \\
\hline & $\begin{array}{c}\text { TC-199E } \\
37^{\circ} \mathrm{C} \\
45 / 122(37)\end{array}$ & $\begin{array}{c}\mathrm{TC}-199 \mathrm{E} \\
39^{\circ} \mathrm{C} \\
92 / 129(71)\end{array}$ & & \\
\hline 2 & $\begin{array}{c}\text { TC-199E } \\
191 / 454(42)\end{array}$ & $\begin{array}{c}\text { KRB } \\
117 / 452(26)\end{array}$ & 15 & $P<0.001$ \\
\hline 3 & $\begin{array}{c}\text { TC-199E } \\
137 / 288(48)\end{array}$ & $\begin{array}{c}\text { TC-199TC } \\
128 / 301(43)\end{array}$ & 7 & $P<0 \cdot 2$ \\
\hline 4 & $\begin{array}{l}\text { TC-199H* } \\
\text { (GIBCO) } \\
51 / 151(34) \\
\text { (KCB) } \\
16 / 74(22)\end{array}$ & $\begin{array}{c}\text { TC-199E } \\
\text { (GIBCO) } \\
109 / 146(75) \\
(\mathrm{KCB}) \\
42 / 75(56)\end{array}$ & $\begin{array}{l}5 \\
2\end{array}$ & $\begin{array}{l}P<0.001 \\
P<0.001\end{array}$ \\
\hline 5 & $\begin{array}{l}\text { TC-199E } \\
(\mathrm{KCB}) \\
68 / 173(39)\end{array}$ & $\begin{array}{c}\text { TC-199E } \\
\text { (GIBCO) } \\
134 / 191(70)\end{array}$ & 4 & $P<0.001$ \\
\hline 6 & $\begin{array}{l}\text { TC-199E } \\
67 / 161(42)\end{array}$ & $\begin{array}{r}\text { TC-199MH } \\
64 / 164(39)\end{array}$ & 3 & $P<0.6$ \\
\hline
\end{tabular}

* Incubated in air atmosphere.

$\mathrm{KRB}$, modified Krebs-Ringer-bicarbonate; PBF, polar body formation; KCB, KC Biological, Inc.

\section{Experiment 1}

Incubation in $\mathrm{TC}-199 \mathrm{E}$ for $48 \mathrm{~h}$ at $39^{\circ} \mathrm{C}$ resulted in a significantly greater $(71 \%)$ rate of polar body formation than at $37^{\circ} \mathrm{C}(37 \%)$.

\section{Experiment 2}

TC-199E was compared to a modified Krebs-Ringer-bicarbonate solution containing glucose, pyruvate, lactate, bovine serum albumin, and antibiotics (Toyoda \& Chang, 1974). This medium has been used successfully to mature cumulus-intact pig oocytes in vitro (Iritani, Niwa \& Imai, 1978; Nagai, Niwa \& Iritani, 1984). As can be seen in Table 1, oocytes cultured in TC-199E formed polar bodies at a greater rate $(42 \%)$ than did those cultured in the Krebs-Ringer-bicarbonate medium $(25 \%)$.

\section{Experiment 3}

There was no difference in the ability of Media TC-199TC and TC-199E to support polar body formation. 


\section{Experiment 4}

Oocytes cultured in Medium TC-199E under $5 \% \mathrm{CO}_{2}$ produced polar bodies twice as often as did oocytes cultured in Medium TC-19H in air. This difference was observed for the media obtained from the two different suppliers.

\section{Experiment 5}

The results of Exp. 4 suggested that there was an effect of source of the culture medium on polar body formation. The results of Exp. 5 confirmed that a higher proportion of polar bodies was found in the oocytes incubated in the GIBCO TC-199E medium.

\section{Experiment 6}

The results of Exp. 6 indicate that the addition of increased bicarbonate to a Hank's based medium (TC-199MH) and subsequent incubation under $5 \% \mathrm{CO}_{2}$ in air allows polar body formation at a rate equal to that observed in an Earle's based medium (TC-199E).

Pig serum and TC-199E from cultures at 0,24 and $48 \mathrm{~h}$ incubation times with egg-cumulus cell complexes were assayed for the presence of pyruvate and lactate. The results are shown in Table 2 .

Table 2. Pyruvate concentrations (mM, mean \pm s.e.m.) in culture medium after incubation with egg-cumulus masses

\begin{tabular}{ll}
\hline Pig serum & $0.207 \pm 0.002$ \\
TC-199E without serum & $0.007 \pm 0.001$ \\
TC-199E after 0 h & $0.035 \pm 0.003$ \\
TC-199E after $24 \mathrm{~h}$ & $0.042 \pm 0.002$ \\
TC-199E after 48 h & $0.060 \pm 0.009$ \\
\hline
\end{tabular}

Pig serum contained $0 \cdot 207 \pm 0.002 \mathrm{~mm}$-pyruvate, while TC-199E without serum contained $0.007 \pm 0.001 \mathrm{~mm}$-pyruvate. TC-199E after 0,24 and $48 \mathrm{~h}$ incubation with egg-cumulus complexes contained $0.035 \pm 0.003 \mathrm{~mm}, 0.042 \pm 0.002 \mathrm{~mm}$, and $0.60 \pm 0.009 \mathrm{~mm}$-pyruvate respectively. None of the media or its components contained detectable levels of lactate.

\section{Discussion}

In the present study, several culture media were compared for their ability to promote polar body formation in immature oocytes. Kuehl \& Dukelow (1979) reported that the inclusion of insulin in a medium based on TC-199 with Earle's salts and L-glutamine did not increase in-vitro maturation or fertilization of monkey ova, although fibroblast monolayers were suppressed. Tsafriri \& Channing (1975) had reported that Medium TC-199 containing added pyruvate, lactate and insulin gave higher rates of germinal vesicle breakdown (GVBD) and polar body formation than did unsupplemented media. In the present study the complex medium of Tsafriri \& Channing (1975) was shown to have no advantage over the simpler formulation lacking these additions.

The difference between the current study and that of Tsafriri \& Channing (1975) may be due to the difference in incubation temperatures used, since Exp. 1 showed that maintaining the cultures at $39^{\circ} \mathrm{C}$ was advantageous to incubation at $37^{\circ} \mathrm{C}$. Lenz, Ball, Liebfried, Ax \& First (1983) reported that fertilization of cow oocytes in vitro was greatest when oocytes were maintained in culture at the core body temperature of the species $\left(39^{\circ} \mathrm{C}\right)$ during maturation as well as during sperm penetration. It seems clear that attention should be paid to the normal body temperature of the species under investigation in future studies of gamete physiology. 
Another difference may be related to the source of pig serum. Tsafriri \& Channing (1975) used serum with low levels of sex hormones. We chose young castrated boars as a serum source likely to have very low levels of sex hormones and this was confirmed by RIA. The serum from many animals was pooled to produce a large single lot, and frozen as $500 \mathrm{ml}$ samples, resulting in a consistent source of pig serum uniformly low in sex steroids.

One major difference between the Media TC-199E and TC-199H is in the buffer system employed. Media based on Earle's salts contain 6-7 times the amount of bicarbonate that is found in media based on Hank's salts. Cultures in Earle's media are usually maintained under an atmosphere of $5 \% \mathrm{CO}_{2}$ in air to maintain the appropriate $\mathrm{pH}$. Media with lower bicarbonate levels (i.e. based on Hank's salts) do not require an atmosphere enriched in $\mathrm{CO}_{2}$.

The vast majority of investigators utilize an atmosphere of $5 \% \mathrm{CO}_{2}$ in air in which to mature or fertilize mammalian oocytes in vitro, although some reports relate to cultures in an atmosphere of air only (Peluso \& Hutz, 1980; De Felici \& Siracusa, 1982; Dekel et al., 1984). In the present study, Medium TC-199 based on a predominately bicarbonate buffer system (Medium TC-199E; Earle's salts) and incubated in $5 \% \mathrm{CO}_{2}$ yielded twice the percentage of polar body formation as the same medium based on a predominately phosphate buffer system (Medium TC-199H; Hank's salts) and incubated in air. When the Hank's based medium was supplemented with extra bicarbonate, however, the percentage of polar body formation was increased to that of the Earle's based medium, demonstrating that bicarbonate ion is required for normal polar body formation. This extends earlier observations (Biggers, Whittingham \& Donahue, 1967; Wales et al., 1969; Quinn \& Wales, 1971, 1973) on the importance of $\mathrm{CO}_{2}$ fixation for the development of preimplantation embryos in culture. Quinn \& Wales (1973) further found that embryos maintained in phosphate-buffered medium had reduced incorporation of low molecular weight precursors into macromolecules.

Oviducal fluid is a rich source of bicarbonate ion (Vishwakarma, 1962; Hamner, 1973; Maas, Storey \& Mastroianni, 1977). Biggers et al. (1967) suggested that carbon dioxide could be fixed via pyruvate carboxylase to form oxaloacetate in the mouse oocyte and zygote. This was strengthened by further reports that the primary energy source in cumulus-free maturing mouse oocytes is pyruvate (Eppig, 1976; De Felici, Vivarelli, Giustiniani \& Siracusa, 1982). Kuehl \& Dukelow (1979) found that pyruvate was beneficial to the in-vitro maturation and fertilization of monkey ova. The ability of cumulus-intact pig oocytes in the present investigation to mature in the absence of exogenous pyruvate may be due to the presence of sufficient pyruvate or equivalent substrate in the supplementing serum. Alternatively, there may be production of pyruvate from glucose via glycolysis in the cumulus cells (Donahue \& Stern, 1968; Leese \& Barton, 1985). In the present report, TC-199E was shown to contain as much pyruvate as was added by Tsafriri \& Channing (1975). Further, there was an increase in pyruvate concentration after egg-cumulus cell complexes had been incubated for 24 and $48 \mathrm{~h}$. It appears therefore that the egg-cumulus cell complexes are capable of producing pyruvate to meet metabolic needs.

We used polar body formation rather than germinal vesicle breakdown as an endpoint for oocyte maturation for two reasons. Firstly, it is our experience that the accurate determination of meiotic stage in fixed and stained whole-mount pig oocytes is problematic, due to the characteristically great amount of yolk in this species. In this regard, we are in agreement with Racowsky \& McGaughey (1982) who resorted to analysis of chromosome spreads. Secondly, we have fixed, embedded in paraffin wax, and serially sectioned a large number of pig oocytes. Germinal vesicle breakdown was observed in $>99.5 \%$ of oocytes which had been cultured, whereas $>95 \%$ of uncultured oocytes had intact germinal vesicles (L. A. Eng, E. T. Kornegay \& J. Huntington, unpublished data). However, the highest rate of polar body formation in the current report was only $75 \%$. These figures are in close agreement with those reported by Motlik, Crozet \& Fulka (1984). The observation of polar body formation is therefore a more stringent criterion of normal physiological oocyte maturation than is germinal vesicle breakdown.

The apparent superiority of media from one supplier over that of another in Exp. 4 and Exp. 5 
should be viewed with caution: only single lots of both Hank's and Earle's based media from each supplier were tested and it is equally likely that differences were due to lot variations.

In summary, the culture of immature pig oocytes at $39^{\circ} \mathrm{C}$ in Medium TC-199E in an atmosphere of $5 \% \mathrm{CO}_{2}$ in air was shown to be superior to other culture regimens tested in promoting polar body formation. Bicarbonate, but not pyruvate, lactate or insulin, was shown to be a necessary component of the culture medium. The requirement for bicarbonate may be related to the metabolic needs of the maturing oocyte.

This work was supported by a grant from the Virginia Agricultural Experiment Station and the Virginia-Maryland Regional College of Veterinary Medicine.

\section{References}

Bailey, N.T.J. (1981) Statistical Methods in Biology, p. 38. Hodder and Stoughton, London.

Biggers, J.D., Whittingham, D.G. \& Donahue, R.P. (1967) The pattern of energy metabolism in the mouse oocyte and zygote. Proc. natn. Acad. Sci. U.S.A. 58, 560-567.

De Felici, M. \& Siracusa, G. (1982) Survival of isolated, fully grown mouse ovarian oocytes is strictly dependent on external $\mathrm{CA}^{2+}$. Devl Biol. 92, 539-543.

De Felici, M., Vivarelli, E., Giustiniani, Q. \& Siracusa, G. (1982) Reversible inhibition of meiosis resumption in mouse dictyate oocytes by suboptimal media. Cell Biol. Int. Rep. 6, 99-104.

Dekel, N., Aberdam, E. \& Sherizly, I. (1984) Spontaneous maturation in vitro of cumulus-enclosed rat oocytes is inhibited by forskolin. Biol. Reprod. 31, 244-250.

Donahue, R.P. \& Stern, S. (1968) Follicular cell support of oocyte maturation: production of pyruvate in vitro. J. Reprod. Fert. 17, 395-398.

Eppig, J.J. (1976) Analysis of mouse oogenesis in vitro. Oocyte isolation and the utilization of exogenous energy sources by growing oocytes. J. exp. Zool. 198, 375-382.

Hamner, C.E. (1973) Oviducal fluid-composition and physiology. In Handbook of Physiology-Section 7: Endocrinology, Vol. II Female Reproductive System, Part 2, pp. 141-151, Eds R. O. Greep \& E. B. Astwood. American Physiological Society, Washington, D.C.

Iritani, A., Niwa, K. \& Imai, H. (1978) Sperm penetration in vitro of pig follicular oocytes matured in culture. $J$. Reprod. Fert. 54, 379-383.

Jaffe, B.M. \& Behrman, H.R. (1974) Methods of Hormone Radioimmunoassay. Academic Press, New York.

Kane, M.T. (1975) Bicarbonate requirements for culture of one-cell rabbit ova to blastocyst. Biol. Reprod. 12, $552-555$.

Kuehl, T.J. \& Dukelow, W.R. (1979) Maturation and in vitro fertilization of follicular oocytes of the squirrel monkey (Saimiri sciureus). Biol. Reprod. 21, 545-556.

Leese, H.J. \& Barton, A.M. (1985) Production of pyruvate by isolated mouse cumulus cells. $J$. exp. Zool. 234, 23I-236.

Lenz, R.W., Ball, G.D., Liebfried, M.L., Ax, R.L. \& First, N.L. (1983) In vitro maturation and fertilization of bovine oocytes are temperature-dependent processes. Biol. Reprod. 29, 173-179.
Maas, D.H.A., Storey, B.T. \& Mastroianni, L., Jr (1977) Hydrogen ion and carbon dioxide content of the oviductal fluid of the rhesus monkey (Macaca mulatta). Fert. Steril. 28, 981-985.

Motlik, J., Crozet, N. \& Fulka, J. (1984) Meiotic competence in vitro of pig oocytes isolated from early antral follicles. J. Reprod. Fert. 72, 323-328.

Nagai, T., Niwa, K. \& Iritani, A. (1984) Effect of sperm concentration during preincubation in a defined medium on fertilization in vitro of pig follicular oocytes. J. Reprod. Fert. 70, 271-275.

Peluso, J.J. \& Hutz, R. (1980) The effect of age on the ability of oocytes to synthesize RNA and proteins during in vitro maturation. Cell Tissue Res. 213, 29-35.

Quinn, P. \& Wales, R.G. (1971) Fixation of carbon dioxide by pre-implantation mouse embryos in vitro and the activities of enzymes involved in the process. Aust. J. biol. Sci. 24, 1277-1290.

Quinn, P. \& Wales, R.G. (1973) Growth and metabolism of preimplantation mouse embryos cultured in phosphate-buffered medium. J. Reprod. Fert. 35, 289-300.

Quinn, P. \& Wales, R.G. (1974) Fixation of carbon dioxide by preimplantation rabbit embryos in vitro. J. Reprod. Fert. 36, 29-39.

Racowsky, C. \& McGaughey, R.W. (1982) Further studies of the effects of follicular fluid and membrane granulosa cells on the spontaneous maturation of pig oocytes. J. Reprod. Fert. 66, 505-512.

Racowsky, C. \& Satterlie, R.A. (1985) Metabolic, fluorescent dye and electrical coupling between hamster oocytes and cumulus cells during meiotic maturation in vivo and in vitro. Devl Biol. 108, 191-202.

Toyoda, Y. \& Chang, M.C. (1974) Fertilization of rat eggs in vitro by epididymal spermatozoa and the development of eggs following transfer. J. Reprod. Fert. 36, 9-22.

Tsafriri, A. \& Channing, C.P. (1975) Influence of follicular maturation and culture conditions on the meiosis of pig oocytes in vitro. J. Reprod. Fert. 43, 149-152.

Vishwakarma, P. (1962) The $\mathrm{pH}$ and bicarbonate-ion content of the oviduct and uterine fluids. Fert. Steril. 13, $48 \mathrm{I}-485$.

Wales, R.G., Quinn, P. \& Murdoch, R.N. (1969) The fixation of carbon dioxide by the eight-cell mouse embryo. J. Reprod. Fert. 20, 541-543.

Received 3 July 1985 